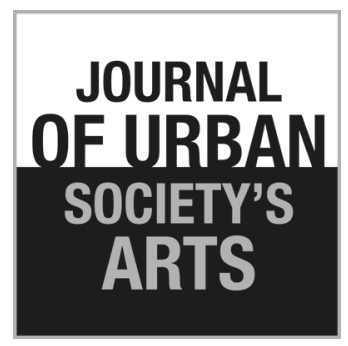

Volume 5 Nomor 1, April 2018: 19-28

\section{Pengaruh Microstock Terhadap Kesadaran Hak Kekayaan Intelektual Desainer Grafis}

\author{
Sonde Martadireja
}

Program Studi Desain Komunikasi Visual, Politeknik Palcomtech

Jl. Basuki Rahmat. No. 5. Palembang.

Sumatera Selatan. 30139

Tlp.085374776619,E-mail: sonde.martadireja@gmail.com

\begin{abstract}
ABSTRAK
Microstock menjadi salah satu unsur penting yang menunjang aktifitas desainer grafis sehari-hari. Baik untuk mendapatkan konten grafis digital, mengetahui perkembangan tren desain kekinian dan menjadi jawaban mereka untuk bekerja secara freelance. Penelitian ini menyajikan apa dan sejauh mana hubungan microstock dengan desainer grafis, kesadaran desainer grafis tentang hak kekayaan intelektual dan fenomena pengaruh microstock terhadap kesadaran hak kekayaan intelektual desainer grafis. Jenis pendekatan yang digunakan adalah fenomenologi Edmund Husserl karena objek yang diteliti berkaitan dengan kesadaran manusia. Fokusnya adalah memaparkan fenomena kesadaran sebagai dasar tindakan yang diperoleh dari pemaknaan pengalaman desainer grafis selama berhubungan dengan microstock. Berdasarkan hasil penelitian, dapat disimpulkan bahwa microstock terbukti memiliki pengaruh terhadap kesadaran desainer grafis tentang hak kekayaan intelektual. Pengalaman-pengalaman tindakan yang berkaitan dengan microstock baik sebagai kontributor maupun non-kontributor telah membentuk suatu pengetahuan baru hingga akhirnya melahirkan kesadaran tentang hak kekayaan intelektual terutama pada masalah lisensi dan royalti. Kesadaran tersebut lalu menjadikan desainer grafis mampu aktif merespon fenomena penghargaan maupun pelanggaran hak kekayaan intelektual di lingkungannya masing-masing.
\end{abstract}

Kata kunci: Microstock; kesadaran; Hak Kekayaan Intelektual

\begin{abstract}
The Influence of Microstock on Graphic Designer's Consciousness of Intellectual Property Right's. Microstock has been one of important elements to support the daily activities of graphic designers. These activities involve finding digital graphic contents, finding out the current development of design trend and becoming their answer to work freelance. This research presents what and to what extent is the relationship between microstock and graphic designers, graphic designer's consciousness of intellectual property rights and the phenomenon of microstock's effect on graphic designers' consciousness of intellectual property rights. The approach used is Edmund Husserl's phenomenology since the object studied is related to human's consciousness. The focus is to elaborate the phenomenon of consciousness as the basis of action which is obtained from interpreting graphic designer's experience when they interact with microstock. Based on the research result, it can be concluded that microstock is found to have some influence on graphic designer's consciousness of intellectual property rights. The experiences of action related to microstock both as contributors and non-contributors have shaped a new knowledge that in turn gives birth to their consciousness of intellectual property rights, particularly on license and royalty issues. This consciousness then allows graphic designers to actively respond to the phenomena of appreciation and violation of intellectual property rights in their own environment.
\end{abstract}

Keywords: Microstock; consciousness; Intellectual Property Right's 


\section{Pendahuluan}

Pada era digital ini, ruang seni dan budaya masyarakat mengalami perubahan seiring perkembangan teknologi dan media informasi. Teknologi menjadi bagian dari relasi dan interaksi, terutama di wilayah perkotaan (Kusrini, 2015). Begitupula dalam aktifitas desainer grafis seharihari. Microstock yang menggunakan teknologi daring telah mewujud sebagai salah satu unsur penting untuk menunjang aktifitasnya. Baik sebagai sarana untuk mendapatkan berbagai konten digital berupa foto, vektor, ilustrasi, video, desain templat, audio, aset tiga dimensi maupun mengetahui perkembangan tren desain kekinian.

Microstock juga menjadi jawaban bagi para desainer grafis untuk bekerja secara freelance. Yaitu bagi mereka yang bertujuan mendapatkan penghasilan tambahan diluar kerja permanen, mempersiapkan diri menjadi full-time freelance, tidak mau menjadi bawahan, mau penghasilan yang lebih besar dan merintis untuk memiliki agensi sendiri (Rustan, 2017). Karena agensi microstock tidak mempersoalkan latar belakang individu yang mau bekerjasama dengannya. Siapapun dia asalkan mengetahui dan menghasilkan karya citra yang bagus maka ia diterima sebagai kontributor. Proses penerimaan karya pun hanya dalam hitungan hari, tidak butuh berminggu-minggu atau bahkan berbulan-bulan (Župič, 2013).

Microstock diidentifikasi sebagai jenis sistem crowdsourcing yaitu suatu model pemecahan masalah secara daring oleh sejumlah besar individu/ kontributor berbentuk perpaduan antara elemen transparan dan demokratisnya open source. Sehingga nantinya kontributor akan memperoleh penghargaan atas solusi yang diberikan dengan format yang jelas. Ini menjadi model yang layak untuk melakukan bisnis yang menguntungkan dan semua difasilitasi melalui web (Brabham, 2008).

Microstock sendiri didefiniskan sebagai market for selling photos online (and also vector images and video) at low prices and with a royalty free licence (Torrens, 2007). Namun menilik perkembangannya hingga saat ini, konten microstock tentu bukan hanya sebatas definisi di atas saja, melainkan juga termasuk aset tiga dimensi dan audio. Konten- konten tersebut berfungsi sebagai bahan mentah yang bisa dikembangkan menjadi sebuah desain yang lebih kompleks sesuai kebutuhan masingmasing konsumen. Misalnya; konten fotografi dimicrostock lebih sebagai pelengkap penjelasan sesuatu, bukan ekspresi makna personal maupun kelompok. Hal ini berbeda dengan fotografi jalanan misalnya,yang merekam cerita perjalanan kehidupan atau segala sesuatu yang ada disepanjang jalan secara fisik (Kusrini, 2016). Dengan macam konten yang semakin beragam, tentu berdampak pada semakin luasnya jangkauan pasar microstock.

Konten yang ditawarkan merupakan kumpulan karya dari para desainer grafis, fotografer, komposer dan animator dari seluruh dunia yang tergabung dan atau terdaftar dalam suatu agensi microstock. Pada hal ini mereka disebut kontributor. Kontributor adalah setiap orang atau kelompok profesional bahkan amatir sekalipun yang terdaftar pada agensi microstock tertentu, dengan perjanjian tertentu, dan mengunggah karya-karya mereka baik berupa foto, vector, ilustrasi, video, desain templat, audio maupun aset tiga dimensi.

Teknisnya adalah, sebelum terbit di laman microstock karya yang diunggah oleh kontributor akan dikurasi terlebih dahulu oleh administrator dengan jarak rata-rata sekitar dua sampai tujuh hari jam kerja. Karya kontributor yang lulus kurasi dan terbit dilaman microstock selanjutnya disebut aset, dan maka berarti karya tersebut telah layak dan siap jual dengan sistem royalty free licence.

Pada salah satu laman agensi microstock yang terkenal yaitu shutterstock, dijelaskan bahwa royalty free adalah suatu metode yang mengacu pada perizinan dimana hak citra dijual dengan harga tetap untuk hampir semua tujuan (Shutterstock, 2010). Dalam arti lain, setiap orang dari seluruh dunia dapat membeli dan menggunakan aset dengan aturan lisensi dari pihak microstock. Sedangkan dari tiap-tiap aset yang terjual, kontributor akan mendapat royalti penjualan. Besaran royalti ini bermacam-macam tergantung pada jenis lisensi yang ditawarkan, jenis aset yang terjual, dan rangking kontributor berdasarkan banyaknya penjualan aset. Lisensi yang dimaksud adalah hak pembeli untuk menggunakan aset yang telah dibeli. Sistem royalty free yang diterapkan oleh 
microstock ini diprediksi bakal berkembang dan menjadi sumber financial baru (Voronov \& Ivanov, 2016).

Bagi kontributor sendiri, aset tidak akan habis/hilang dari situs microstock walaupun sudah bekali-kali terjual, kecuali bila dibeli secara ekslusif. Sedangkan royalti adalah aturan finansial yang dibuat berdasarkan perjanjian perpajakan antara negara tempat pusat agensi microstock berada dengan negara tempat tinggal pengunggah /kontributor dan pengunduh aset. Misalnya pada situs adobe stock, aturan royalti dibuat dengan didasarkan pada sistem perpajakan antar negara yang dikenal sebagai W-8Ben. Peraturannya didasarkan pada perjanjian perpajakan Amerika Serikat (negara pusat tempat adobe stock berada) dengan negara Indonesia (negara tempat penunggah dan pengunduh aset). Calon kontributor yang mendaftar disitus microstock akan diminta sistem untuk mengisi formulir tersebut.

Banyak agensi microstock yang berkembang cukup pesat seperti shutterstock, istock by getty images, fotolia, 123rf, dreamstime, freepik, dan bahkan perusahaan besar yang bergerak dalam bidang aplikasi perangkat lunak desain, Adobe, juga memiliki agensi microstock sendiri sebagai pengembangan dari fotolia yang telah diakuisisinya (Brady \& Saviage, 2015), microstok tersebut adalah adobe stock.

Berdasarkan narasi umum mengenai microstock di atas, maka penulis tertarik mengungkap fenomena hubungan microstock dengan kesadaran hak kekayaan intelektual desainer grafis dalam dua sisi. Pertama, dari sisi desainer grafis sebagai kontributor (yang menjual aset di agensi), dan kedua, desainer grafis sebagai non-kontributor (yang membeli aset di agensi). Diasumsikan bahwa jika desainer grafis telah bersinggungan dengan dunia microstock baik sebagai kontributor maupun non-kontributor, maka pengalaman tersebut akan menimbulkan kesadaran yang menghasilkan tindakan (act) berkaitan dengan hak kekayaan intelektual. Mekanismenya, kontributor akan berhubungan dengan royalti atas karya-karyanya yang dijual diagensi microstock, sedangkan non-kontributor harus berhubungan dengan aturan-aturan lisensi jika ingin mendapatkan dan menggunakan aset secara legal.

Permasalahan hak kekayaan intelektual merupakan suatu hal yang terus berkembang sesuai dengan perkembangan ilmu pengetahuan dan teknologi (Chalim, 2011). Dalam menyikapi perkembangan kekinian dunia desain dengan segala kaitannya tersebut, perhatian akan pengetahuan dan tindakan desainer grafis tentang hak kekayaan intelektual sangat diperlukan (di Indonesia mengacu pada Undang-Undang Nomor 28 Tahun 2014 tentang hak kekayaan intelektual).

Tindakan-tindakan ilegal seperti pencatutan karya desain secara curang untuk tujuan komersial ataupun non-pendidikan dan penggunaan perangkat lunak ilegal untuk memproduksi desain grafis masih saja marak. Tindakan serampangan dan apatis ini dikhawatirkan dapat menghambat kemajuan desainer grafis itu sendiri. Oleh sebab itu, keberadaan hak kekayaan intelektual menjadi penting karena tidak hanya akan memberikan nilai ekonomis bagi pemegang hak, tetapi juga memberikan motivasi yang lebih besar bagi para desainer grafis untuk mengembangkan daya cipta dan kreativitasnya (Banindro, 2015). Semakin tinggi penghargaan negara terhadap hak kekayaan intelektual, maka masa depan suatu bangsa akan menjadi lebih baik (Mastur, 2012).

Sebetulnya telah banyak penelitian yang menawarkan solusi untuk mengatasi problem/ masalah-masalah yang muncul dalam perlindungan hak cipta di Indonesia. Diantaranya adalah sosialisasi terhadap pentingnya penghormatan hak cipta, peningkatan kesadaran hukum bagi masyarakat, peningkatan ekonomi masyarakat, dukungan pemerintah dalam Undang-Undang Hak Cipta, dan meningkatkan kualitas para penegak hukumnya melalui pendidikan supaya dapat menegakkan keadilan dan mencari kebenaran dalam menangani kasus-kasus pelanggaran pelanggaran hak cipta pada khususnya (Mashdurohatun, 2012). Namun begitu, perlu juga dipertimbangkan bahwa setiap pelangaaran hak kekayaan intelektual di Indonesia bukan tanpa alasan. Hak kekayaan intelektual juga menimbulkan permalasahan, diantaranya menciptakan monopoli yang mengakibatkan harga tinggi sehingga sebagian besar masyarakat 
Indonesia tidak memiliki daya beli yang cukup, atau juga bahkan pembajakan malah sebagai sumber mata pencaharian (Imaniyati, 2015).

Pada penelitian ini, mengingat pentingnya isu hak kekayaan intelektual terutama bagi desainer grafis, maka penulis akan menganalisis dan menyajikan bagaimana fenomena pengaruh microstock terhadap desainer grafis baik perannya sebagai kontributor maupun non-kontributor tentang kesadaran hak kekayaan intelektual. Karena berbicara tentang kesadaran, maka penelitian ini akan mengupas pengalaman, pemaknaan, dan tindakan manusia (dalam hal ini desainer grafis) terhadap sesuatu yang disadarinya tersebut (hak kekayaan intelektual).

Landasan teori yang digunakan adalah fenomena kesadaran manusia menurut Edmund Husserl (2002) yang menegaskan bahwa kesadaran adalah intensionalitas. Aktifitas subyek (penelitian) yang terdiri dari mengingat (remembering); mencerap/mengerti (perceiving) dan menghendaki (desiring), ketiganya mengarah (directedness) kepada pengalaman/ peristiwa; pengetahuan tentang "sesuatu" atau keindahan dan kebaikan. Inilah yang disebut dengan intensionalitas (Supriadi, 2015).

Pada dasarnya, fenomenologi berkonsentrasi pada aktivitas kesadaran dan objek yang menampilkan diri pada kesadaran. Husserl menyadari relasionalitas kesadaran yang esensial, yaitu kesadaran pada dasarnya adalah medium antara seseorang dan dunia (Giorgi, 2012). Yaitu bahwa kesadaran merupakan representasi dari sesuatu hal yang ada di dunia sekeliling manusia. Atau dengan kata lain, kesadaran merupakan sebuah tindakan mewujudkan (act) yang didasari oleh pengalaman yang merujuk pada sesuatu. Karena kesadaran ditandai oleh intensionalitas, maka fenomen harus dimengerti sebagai apa yang menampakkan diri (Ajidarma, 2003).

\section{Metode}

Penelitian ini menggunakan pendekatan fenomenologi Edmund Husserl. Jenis pendekatan ini dipilih karena objek yang diteliti berkaitan dengan kesadaran manusia. Fenomenologi ini mempelajari dengan melukiskan ciri-ciri intrinsik dari gejala sebagaimana gejala itu menyingkapkan dirinya pada kesadaran (Sudarman, 2017). Fenomenologi juga menuntut dua hal. Pertama, data kesadaran yang berasal dari celah-celah pengalaman dinamis berupa objek yang dicapai dalam kesadaran (noema) dan bersifat rasio. Kedua, analisis rasional terhadap data dan meletakkannya dalam logika kesadaran (analisis rasional atas noesis dan noema) atau realitas kesadaran (Mu'ammar, 2017).

Fokus penulisan ini adalah pengaruh microstock terhadap kesadaran hak kekayaan intelektual desainer grafis. Yaitu memaparkan fenomena (noesis dan noema) kesadaran sebagai dasar tindakan yang diperoleh dari pemaknaan pengalaman desainer grafis selama berhubungan dengan industri microstock. Sumber data yang digunakan untuk menganalisis fenomena ini berasal dari studi pustaka, wawancara, kuesioner, dan observasi partisipatif.

Industri microstock yang dipilih sebagai sampel adalah agensi yang umum digunakan desainer grafis baik dia berperan sebagai kontributor maupun non-kontributor. Umum yang dimaksud diperoleh dari data pustaka, wawancara, dan observasi partisifatif, yaitu penulis turut berperan sebagai konrtibutor dan non-kontributor pada agensi-agensi microstock. Sampel agensi terpilih adalah adalah adobe stock, fotolia, shutterstock, istock by getty images, freepik, dan $123 \mathrm{rf}$.

Pada dasarnya adobe stock dan fotolia berada pada satu manajeman yang sama (saat ini, setelah fotolia diakuisisi oleh adobe). Dipilihnya agensi ini adalah karena merupakan produk dari perusahaan besar yang juga memproduksi perangkat lunak populer untuk membuat desain grafis. Sehingga adobe stock menjadi familier dikalangan desainer grafis praktisi. Selain itu, setiap perangkat lunak adobe terbaru (seri creative cloud/CC) akan otomatis terintegrasi dengan adobe stock, baik itu aplikasi desktop (komputer pribadi/ PC) maupun mobile (telepon selular). Aplikasi dekstop antara lain: adobe photoshop CC, adobe illustrator CC, adobe inDesign CC, adobe animate CC, dan adobe premier CC, dan lainnya. Aplikasi mobile yaitu adobe sketch, adobe illustrator draw, adobe lightroom for mobile, adobe premiere clip, dan lainnya. 
Shutterstock dipilih karena sebagian besar desainer grafis yang menjadi kontributor menempatkan shutterstock pada urutan pertama sebagai agensi yang memberikan royalti (earning) terlancar. Data ini didapat dari observasi pada forum kontributor microstock besar di Indonesia dan cukup aktif di media sosial, yaitu Microstock Indonesia Raya di facebook.

Istock by getty images dipilih karena merupakan agensi microstock tua yang memiliki banyak kontributor dan dikenal cukup luas. Istock (microstock) merupakan cabang dari getty images (macrostock). Aset-aset dari agensi ini telah banyak digunakan dalam produksi film-film kelas dunia. Istock sendiri telah banyak dijadikan model sumber kajian ilmiah, terutama dalam bidang crowdsourcing.

Freepik dipilih karena kepopulerannya dikalangan desainer grafis kontributor maupun non-kontributor. Kepopuleran ini karena freepik membagi aset menjadi dua jenis dengan relatif cukup jelas. Yaitu aset gratis dan aset berbayar. Selain itu, freepik memiliki gaya pemasaran yang terbilang berbeda dengan agensi lainnya. Yaitu banyaknya aset gratis yang ditawarkan oleh agensi ini terbukti mampu menarik perhatian desainer non-kontributor. Namun begitu, gratis dalam artian ini sebenarnya tetap tidak bisa digunakan secara bebas. Artinya, aset tetap memiliki aturan lisensi tertentu sehingga setiap desainer grafis yang tergabung menjadi kontributor di freepik mendapatkan royalti.

123rf dipilih karena sebagian desainer grafis yang pada awal karirnya sebagai kontributor microstock akan memilih agensi ini. Selain memiliki sistem kurasi yang relatif tidak ketat, juga melayani cara pembelian aset yang mudah bagi para non-kontributor lokal (Indonesia). Yaitu telah dalam bentuk rupiah dan bisa menggunakan paypal.

Desiner grafis yang dipilih sebagai responden kuesioner penelitian ini adalah para individu maupun kelompok yang memiliki keterampilan, pengetahuan, dan bertindak dalam bidang desain grafis baik dari kalangan akademis maupun nonakademis. Mereka menghasilkan karya digital baik dalam bentuk seni vektor, ilustrasi bitmap, desain templat, video pendek, audio dan aset tiga dimensi. Selanjutnya desainer grafis ini dikelompokkan lagi menjadi dua yaitu: pertama, sebagai kontributor (yang menjual aset diagensi), dan kedua, desainer grafis non-kontributor (yang membeli maupun mengunduh aset gratis diagensi). Keduanya berasal dari kalangan mahasiswa desain komunikasi visual, desainer grafis yang bekerja pada perusahaan desain dan percetakan, dosen dan guru desain komunikasi visual dan para kontributor microstock aktif yang tergabung dalam komunitas Microstock Indonesia Raya di media sosial facebook.

Kuesioner dan wawancara berisi pertanyaanpertanyaan dengan pilihan jawaban yang telah ditentukan sebelumnya oleh peneliti. Pertanyaanpertanyaan tersebut berkaitan dengan latar belakang desainer grafis, pengalaman, pemaknaan; pendapat, perasaan, pengetahuan, dan tindakan. Untuk dapat menjangkau responden yang lebih luas, maka kuesioner ini dibuat dengan menggunakan google forms dan disebar secara daring melalui surel, dan media sosial seperti; facebook, whatsApp, telegram, dan messenger.

Observasi partisipatif dilakukan oleh peneliti dengan cara ikut aktif sebagai kontributor maupun non-kontributor di industri microstock. Wawancara dilakukan dengan menemui langsung responden maupun melalui obrolan daring. Studi pustaka diperoleh dari perpustakaan daring maupun nondaring dan dari laman terkait.

Analisis dilakukan dengan cara mendeskripsikan secara objektif data-data yang telah terhimpun dari studi pustaka, wawancara, kuesioner dan observasi partisipatif. Kemudian peneliti membuat sintesis berdasarkan teori fenomenologi kesadaran oleh Edmund Husserl untuk dapat menyajikan noesis (objek dari kesadaran) dan noema (kesadaran dari objek) pengaruh industri microstock terhadap kesadaran hak kekayaan intelektual desainer grafis.

\section{Pembahasan}

Penjelasan fenomena pengaruh mikrostock terhadap kesadaran hak kekayaan intelektual desainer grafis akan diawali oleh deskripsi tentang apa dan sejauh mana hubungan industri microstock 
dengan desainer grafis. Lalu dilanjutkan dengan deskripsi kesadaran desainer grafis tentang hak kekayaan intelektual.

\section{Hubungan Microstock dengan Desainer Grafis}

Berikut dapat dilihat apa dan sejauhmana hubungan microstock dengan desainer grafis:

Pertama, terdapat 27\% desainer grafis yang tidak mengenal microstock, dan $73 \%$ yang mengenal microstock. Ini menandakan bahwa ada sebagian kecil desainer grafis yang tidak mengenal microstock. Penyebabnya adalah, desainer grafis yang sering menggunakan situs-situs penyedia aset grafis secara gratis ataupun berbayar dan mencari konten desain digital dengan mengandalkan peramban gambar (google, yahoo, bing, dan lainnya), tidak mengetahui bahwa aset grafis sebagian besar berasal dari agensi-agensi microstock (shutterstock, fotolia, freepik, adobe stock, istock, dan lainnya) atau juga sistem tersebut bernama microstock.

Kedua, desainer grafis non-kontributor (67\%) lebih banyak dibanding kontributor (33\%). Mereka yang menjadi kontributor ini sebagian besar baru dimulai semenjak dua tahun belakangan $(73,4 \%)$. Jika dilihat dalam skala global, kontributor Asia (termasuk Indonesia), Amerika latin, Afrika dan Australia memang masih lebih sedikit dibanding kontributor (dalam hal ini fotografer) yang berlokasi di Eropa. Tempat mereka tergabung terutama di agensi-agensi negara Eropa dan Amerika Serikat, dan memproduksi $80 \%$ konten visual di agensiagensi tersebut (Kalazic, Horvat, \& Mijoc, 2015)

Ketiga, jenis grafis yang paling banyak diunggah oleh kontributor adalah vector $(75,9 \%)$, dan jenis grafis yang paling banyak diunduh nonkontributor adalah juga vector $(64,8 \%)$. Seiring dengan itu, bahwa bermula dari pencarian vector di internet, mayoritas desainer grafis mulai mengenal microstock. Untuk keperluan desain grafis, jenis vector memang memiliki lebih banyak kelebihan dibanding bitmap. Selain mudah diedit atau diolah kembali, hasil grafis vector tidak pecah walau diperbesar.

Keempat, bahwa mayoritas populasi berpendapat microstock sangat membantu, yaitu sebanyak 93,9\%. Alasan pendapat ini adalah karena memang agensi microstocklah yang dominan menyediakan berbagai aset grafis dengan kualitas bagus (karena telah dilakukan proses kurasi terlebih dahulu sebelum ditampilkan pada laman masingmasing agensi). Oleh sebab itu, para desainer grafis menjadi terbantu dengan melimpahnya alternatif grafis berkualitas.

\section{Kesadaran Desainer Grafis tentang Hak Kekayaan Intelektual}

Uraian kesadaran desainer grafis tentang hak kekayaan intelektual dimulai dengan gambaran pengetahuan awal mengenai lisensi dan royalti di microstock. Sebagaimana dijelaskan sebelumnya, lisensi dan royalti merupakan sebagian pengetahuan dari hak kekayaan intelektual dan menjadi isu penting dalam dunia microstock. Pengetahuan ini menjadi modal dasar dalam memaknai pengalamannya tentang seluk beluk hak kekayaan intlektual.

Sebelum mengenal microstock, lebih dari separuh populasi desainer grafis telah mengetahui secara umum tentang lisensi dan royalti (66,7\%). Setelah mengenal microstock, terdapat pertumbuhan pengetahuan desainer grafis tentang lisensi dan royalti tersebut. Hasil data menunjukkan pertumbuhan pengetahuan itu sebanyak 20,1\%.

Berkaitan dengan pengetahuan tentang norma hak kekayaan intelektual, pada dasarnya sebagian besar (93\%) setuju bahwa menggunakan karya desainer grafis lain tanpa memperdulikan hak kekayaan intelektual adalah tindakan yang tidak bijak. Para desainer grafis tersebut juga merespon bahwa penghargaan tentang hak kekayaan intelektual dilingkungan masing-masing belum baik, yaitu sebanyak 93\%.

Populasi desainer grafis menganggap bahwa hak kekayaan intelektual pada karya-karya desainer grafis sangat penting. Baik itu untuk menghasilkan dampak finansial maupun sebagai penghargaan atas karya. Mereka juga mengharap ada kemajuan penghargaan hak kekayaan intelektual desainer grafis dilingkungannya masing-masing. Cara awal untuk mencapai itu adalah dengan tindakan sosialisasi yang lebih masif mengenai pengetahuan 
hak kekayaan intelaktual pada desainer grafis maupun masyarakat terkait. Pendapat dan harapan ini merupakan gambaran tindakan (act) yang dilakukan desainer grafis setelah tersadarkan pengetahuannnya tentang hak kekayaan intelektual.

\section{Fenomena Pengaruh Microstock terhadap Kesadaran Hak Kekayaan Intelektual Desainer Grafis}

Dunia desain grafis mengalami peralihan tren yang begitu cepat. Bahkan dalam kurun waktu satu tahun, tren desain bisa beberapa kali berubah. Sebuah desain populer yang dibuat oleh para desainer (termasuk juga desainer grafis pemula), akan segera tumbang digantikan oleh tren desain yang baru. Sebagai contoh, tren desain WPAP (Wedha's Pop Art Portrait) kini mulai ditinggal oleh para desainer grafis dan penikmat karya desain. Tentu saja hal ini disebabkan karena adanya semacam kejenuhan dan alternatif desain lain yang dirasa lebih dapat memikat hati masyarakat.

Melaui internet, baik para desainer maupun penikmat karya, selalu diberi alternatif gaya desain yang bagus terus-menerus setiap waktu. Bila alternatif tersebut bisa menarik perhatian, maka ia akan populer dan dalam kata lain disebut viral. Lalu gaya desain itu diikuti atau ditiru oleh desainer-desainer grafis, baik karena diminta oleh masyarakat umum ataupun karena kesadaran desainer grafis sendiri. Alternatif-alternatif gaya tersebut banyak bersumber dari laman microstock. Karena memang setiap agensi microstok berlombalomba untuk menampilkan aset mereka yang terbaik dari kontributor seluruh dunia. Oleh sebab itu, dapat dikatakan bahwa microstock memiliki andil besar dalam menentukan persepsi tren desain kekinian, dan persepsi merupakan langkah sebelum kesadaran.

Saat memproduksi karya desain dikesehariannya, desainer grafis terkadang tertekan oleh waktu tenggat pengerjaan (deadline) yang sangat sempit. Hal ini bisa terjadi oleh banyak sebab seperti, manajemen produksi yang tidak terkontrol, egoisme pemilik proyek, ataupun desakan kebutuhan yang mengharuskan desainer grafis mengambil konsekuensinya. Untuk menyiasati hal tersebut, terutama bagi para desainer grafis yang mengerjakan perbagian desain secara individu (seperti membuat gambar ilustrasi, fotografi dan huruf seorang diri), maupun yang memiliki kemampuan terbatas, maka akan mencari referensi melalui internet atau juga mengunduh desain siap edit agar karya cepat selesai. Namun karena setiap desainer grafis memiliki kesadaran yang berbedabeda tentang bagaimana memanfaatkan konten digital sebagaimana mestinya, maka kemungkinan pelanggaran-pelanggaran hak kekayaan intelektual menjadi besar.

Apalagi pada arena teknologi internet ini. Minimnya pengawasan dari hukum terkait akan sangat menggoda para desainer grafis untuk melanggar hukum dan norma yang berlaku. Teknologi telah menjadi pedang bermata dua karena selain memberikan kontribusi bagi peningkatan kesejahteraan, kemajuan, kecerdasan, dan peradaban manusia, sekaligus menjadi sarana perbuatan melawan hokum (Renouw, 2017).

Mengunduh aset grafis gratis dari hasil pencarian peramban memang rawan tindakan plagiat dan pengabaian hak kekayaan intelektual. Terutama oleh meraka yang hanya mengandalkan hasil pencarian dari peramban gambar saja. Teknisnya adalah, agensi microstock menyediakan aset grafis gratis dan berbayar (keduanya memiliki syarat-syarat tertentu yang mengikat pengguna). Hasil deteksi peramban gambar mencakup keduanya (gratis dan berbayar). Lalu desiner grafis yang menggunakan mesin peramban akan dihadapkan pada dua pilihan, yaitu aset grafis gratis dan berbayar yang ditandai oleh penggunaan watermark. Aset gratis dapat langsung diunduh file aslinya untuk menghilangkan watermark (jika ada), sedangkan aset berbayar harus dibeli terlebih dahulu agar bisa diunduh file aslinya untuk menghilangkan watermark.

Secara spontan, tentu mereka lebih memilih grafis bagus tanpa watermark. Namun ada kecenderungan bahwa setiap hasil grafis terpilih akan langsung diunduh tanpa melihat peraturan apa yang disertakan oleh agensi. Padahal setiap aset gratis tersebut memiliki aturan-aturan tertentu yang menyertainya. Sebagai contoh, meraka yang menggunakan aset gratis (unsubscribed user) dari 
freepik diharuskan menulis nama desainer dan agensi saat menggunakannya baik untuk keperluan desain situs maupun cetak, yaitu "designed by (desainer name)/freepik".

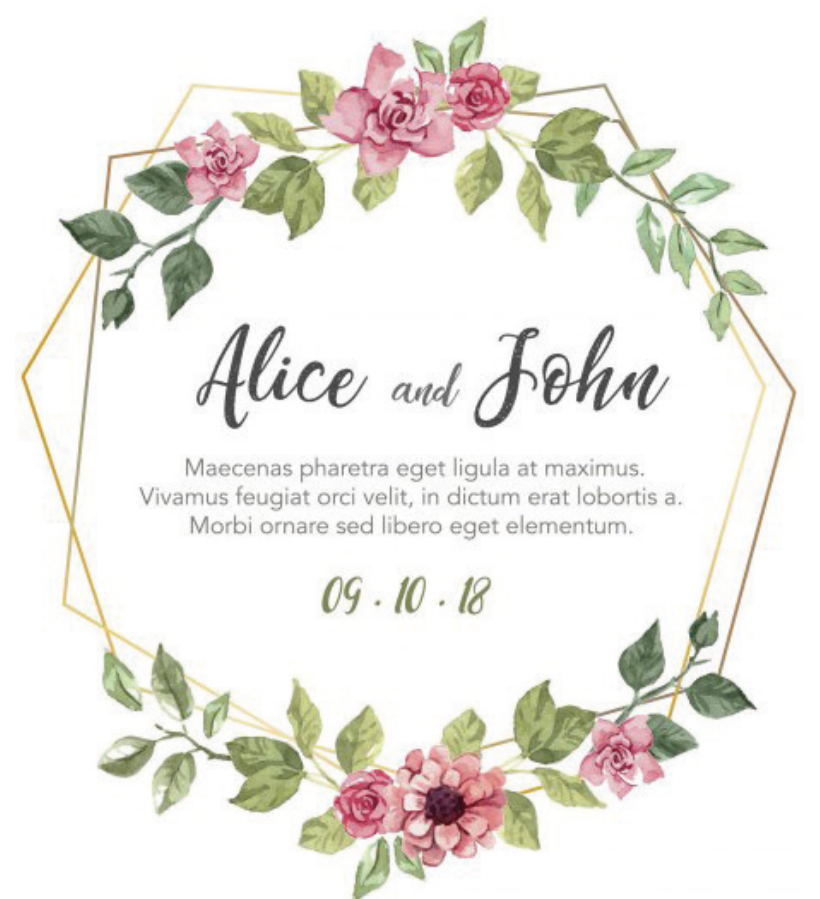

Gambar 1. Aset vector gratis dari freepik tanpa watermark. (Sumber: Freepik, 2018)

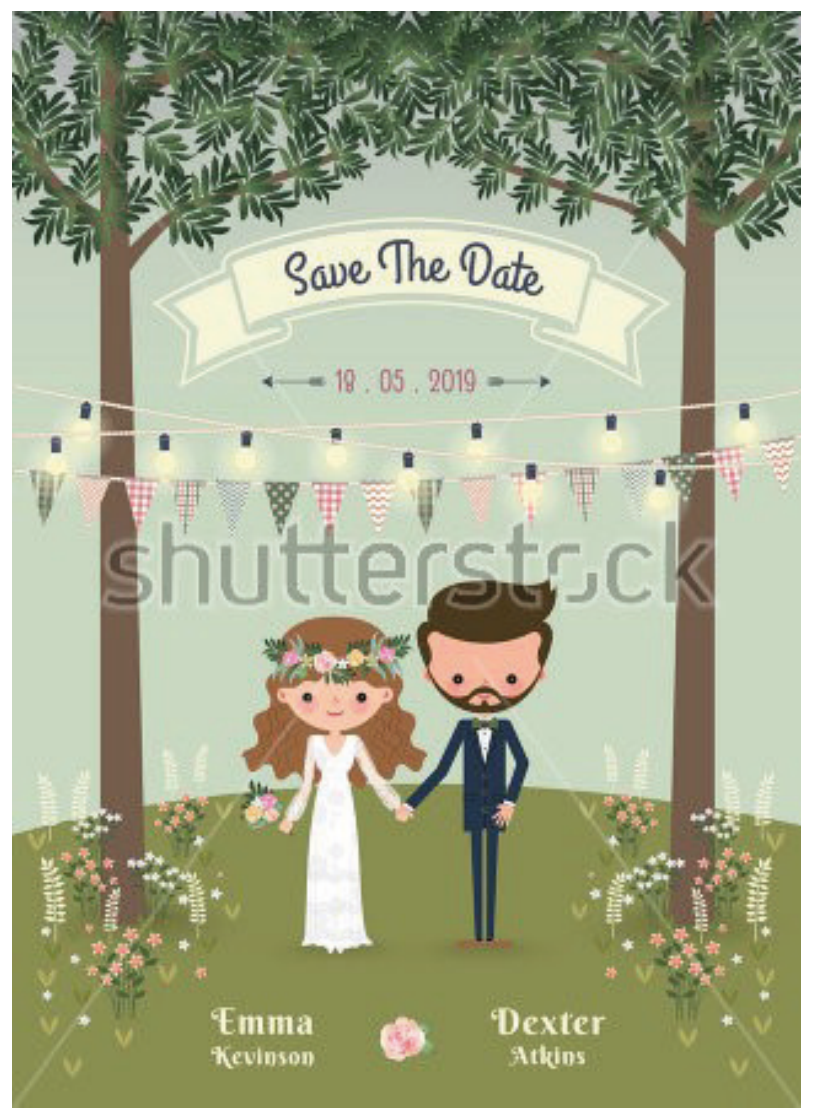

Gambar 2. Aset vector berbayar dari shutterstock menggunakan watermark. (Sumber: Shutterstock, 2018)
Para desainer grafis yang ingin bebas pelanggaran hukum, maka mau tidak mau harus mengikuti aturan tentang aturan lisensi yang telah disiapkan perpaket oleh agensi. Sedangkan bagi desainer grafis yang memanfaatkan microstock untuk dampak ekonomi (kontributor), dihadapkan pada aturan royalti yang telah juga disiapkan aturannya oleh agensi microstock. Dua hal ini (lisensi dan royalti) memang hanya sebagian dari keseluruhan aturan tentang hak kekayaan intelektual, namun mencukupi untuk menjadi pondasi penting pemahaman berbagai aturan-aturan terkait lainnya.

Normalnya memang kejelasan aturan yang disertakan dalam industri microstock bisa meminimalisir pelanggaran hak kekayaan intelektual. Namun tidak bisa diabaikan juga bahwa beberapa hal seperti sempitnya tenggat waktu pengerjaan, pengawasan dan pelaksanaan jalannya penerapan humum hak kekayaan intlektual, kendala bahasa, kondisi ekonomi, maupun kebiasaan sosial, menjadi suatu realitas yang bisa menjelaskan kenapa pelanggaran hak kekayaan intlektual di dunia microstock bisa terjadi. Atau juga menurut Saidin (2016) bahwa, faktor-faktor yang menyebabkan ketidakpatuhan masyarakat terhadap hukum selalu diawali dari norma hukumnya sendiri yang tidak memberikan suasana nyaman kepada anggota masyarakat.

Mengacu pada teori kesadaran Husserl, dapat dikatakan bahwa dari uraian pengalamanpengalaman di ataslah kesadaran para desainer grafis tentang hak kekayaan intelektual (khususnya tentang lisensi dan royalti) semakin bertumbuh. Inilah yang disebut intensionalitas, yaitu bahwa kesadaran selalu merujuk pada sesuatu. Atau dengan kata lain, sesuatu yang dirujuk tersebut adalah hak kekayaan intelektual, dan tindakan atau respon aktif yang dibentuk oleh pengalaman-pengalaman mengenai hak kekayaan intelektual adalah sebagai akibat dari pengaruh industri microstock terhadap desainer grafis yang selanjutnya disebut kesadaran.

Kesadaran akan mengembangkan tindakan desainer grafis sehingga ia tidak pasif. Perkembangan dari kesadaran tentang hak kekayaan intelektual tercermin melalui terbentuknya kemampuan untuk merespon terhadap hal-hal yang berkaitan dengan pengetahuan barunya tersebut. Terutama respon 
mengenai penghargaan maupun pelanggaran hak kekayaan intelektual dilingkungan masing-masing.

\section{Simpulan}

Secara ringkas, pengaruh microstock terhadap kesadaran hak kekayaan intelektual desainer grafis adalah sebagai berikut;

1. Hubungan microstock dengan desain grafis dapat dilihat dari hal-hal berikut, yaitu; sampai penelitian ini dibuat telah ada sebagain besar desainer grafis yang mengenal microstock, desainer grafis non-kontributor microstock lebih banyak dibanding kontributor, jenis grafis yang paling banyak diunggah dan diunduh oleh desainer grafis dari microstock adalah vector dan mayoritas populasi desainer grafis berpendapat bahwa microstock sangat membantu aktivitas berkarya mereka.

2. Kesadaran desainer grafis tentang hak kekayaan intelektual dapat dilihat pada hal-hal berikut, yaitu; terdapat pertumbuhan pengetahuan hak kekayaan intlelektual (terkhusus pada soal lisesnsi dan royalti) antara sebelum dengan sesudah desainer grafis mengenal microstock, desainer grafis merespon bahwa penghargaan hak kekayaan intelektual dilingkungan masingmasing belum baik, dan populasi desain grafis menganggap bahwa hak kekayaan intelektual sangat penting baik untuk menghasilkan dampak finansial maupun sebagai penghargaan atas karya.

3. Pengalaman-pengalaman desainer grafis baik sebagai non-kontributor maupun kontributor yang berkaitan dengan lisensi dan royalti sebagai akibat dari hubungannya dengan industri microstock akan melahirkan pengetahuan baru. Lalu perngetahuan baru itulah yang membentuk kesadaran tentang Hak Kekayaan Intelektual. Inilah yang disebut sebagai intensionalitas. Yaitu bahwa kesadaran selalu merujuk pada sesuatu. Atau dengan kata lain, sesuatu yang dirujuk tersebut adalah Hak Kekayaan Intelektual.

4. Kesadaran hak kekayaan intelektual membentuk desainer grafis untuk dapat aktif merespon segala hal yang berkaitan dengan pengetahuannya tersebut.
Sebagaimana khas kajian fenomenologi Husserl, Penelitian ini hanyalah salah satu profil dari sekian banyak kemungkinan profil-profil lain. Karena penulisan dalam penelitian fenomenologi didasarkan pada ide bahwa tidak ada teks yang sempurna, tidak ada interpretasi yang lengkap, tidak ada eksplikasi dari makna yang berakhir, tidak ada wawasan diatas tantangan itu sendiri (Rakhmawati, 2012). Peneliti lain dapat mengkaji dari berbagai sudut, jarak, dan cara pandang yang berbeda untuk mengungkap profil lain.

\section{Ucapan Terima Kasih}

Puji dan syukur kepada Allah atas segala rahmat hidayah yang diberikan sehingga dapat menyelesaikan dan membagikan hasil penelitian melalui jurnal ini. Terima kasih juga penulis sampaikan pada para pakar yang telah meluangkan waktunya untuk mereview artikel ini, dewan Redaksi Journal of Urban Society's Art dan jajaran Akademis Program Studi Desain Komunikasi Visual Politeknik Palcomtech.

\section{Kepustakaan}

Ajidarma, S. G. (2003). Kisah Mata: Fotografi Antara Dua Subyek: Perbincangan Tentang Ada. Yogyakarta: Galang Press. Retrieved from https://books.google.co.id/ books?id=KmC5 $2 \mathrm{~m} 1 \mathrm{yHgC}$

Banindro, Baskoro Suryo. (2015). Implementasi Hak Kekayaan Intelektual(Hak Cipta, Merek, Paten, Desain Industri) Seni Rupa, Kriya dan Desain. BP ISI Yogyakarta.

Brabham, D. C. (2008). Crowdsourcing as a model for problem solving: An introduction and cases. Convergence, 14(1), 75-90.

Brady, R., \& Saviage, M. (2015). Adobe Completes Acquisition of Fotolia Vibrant Image and Video Marketplace to Be Integrated as Key Part of Adobe Creative Cloud. Retrieved October 14, 2018, from www.adobe.com

Chalim, M. A. (2011). Pengaruh Perkembangan IPTEK Terhadap Permasalahan HAKI. Jurnal Dinamika Hukum, 11, 47-58.

Giorgi, A. (2012). The Descriptive Phenomeno- 
logical Psychological Method. Journal of Phenomenological Psychology, 43(1), 3-12.

Husserl, E. (2002). The shorter logical investigations. Routledge.

Imaniyati, N. S. (2015). Perlindungan HKI Sebagai Upaya Pemenuhan Hak Atas IPTEK, Budaya dan Seni. Jurnal Media Hukum, 17(1).

Kalazic, Z., Horvat, J., \& Mijoc, J. (2015). The Stock Photography As A Part Of Cultural And Creative Industries Of The Digital Age. Interdisciplinary Management Research, 11, 189-203.

Kusrini. (2015). Potret Diri Digital dalam Seni dan Budaya Visual. Journal of Urban Society's Arts, 2(2), 111-122. https://doi.org/10.24821

Kusrini. (2016). Fotografi Jalanan: Membingkai kota dalam cerita. Journal Of Urbarn Society's Arts, 3(2), 101. https://doi.org/10.24821

Mashdurohatun, A. (2012). Problematika Perlindungan Hak Cipta di Indonesia. Yustisia Jurnal Hukum, 1(1), 71-89.

Mastur, M. (2012). Perlindungan Hukum hak kekayaan intelektual Dibidang Paten. QISTIE JURNAL ILMU HUKUM, 6(1), 65-81.

Mu'ammar, M. N. (2017). Analisis Fenomenologi Terhadap Makna dan Realita. Jurnal Studi Agama Dan Masyarakat, 13(1), 120-135.

Rakhmawati, Y. (2012). Membaca Pengalaman dan Kesadaran: Konstruksi dalam Perspektif Fenomenologi. Pamator Journal, 5(2), 89-95.

Renouw, D. M. E. (2017). Perlindungan Hukum E-Commerce. (Servas Pandur, Ed.) (Cetakan Pe). Jakarta: Yayasan Taman Pramuka.

Rustan, S. (2017). Bisnis Desain (2017th ed.). Jakarta: PT Lintas Kreasi Imaji.

Saidin, O. (2016). Sejarah dan politik hukum hak cipta. Jakarta: PT RajaGrafindo Persada.
Shutterstock. (2010). Ask Shutterstock: What Does Royalty-Free Mean? - The Shutterstock Blog. Retrieved October 14, 2018, from https:// www.shutterstock.com/blog/ask-shutterstockwhat-does-royalty-free-mean

Sudarman, S. (2017). Fenomenologi Husserl Sebagai Metode Filsafat Eksistensial. AlAdyan, 9(2), 103-113.

Supriadi, S. (2015). PERKEMBANGAN FENOMENOLOGI PADA REALITAS SOSIAL MASYARAKAT DALAM PANDANGAN EDMUND HUSSERL. Scriptura, 5(2), 52-61.

Torrens, L. (2007). What is Microstock Photography? Retrieved August 6, 2018, from http://www.microstockdiaries.com/what-ismicrostock.html

Voronov, V. S., \& Ivanov, V. V. (2016). The rise of cyber market for stock art: Assets aggregation and the wealth of mass creativity. Proceedings of the 27th International Business Information Management Association Conference-Innovation Management and Education Excellence Vision 2020: From Regional Development Sustainability to Global Economic Growth, IBIMA 2016, 537-545. Retrieved from http:// www.scopus.com/inward/record.url?eid=2s2.0-84984626874\&partnerID=tZOtx3y1

Župič, I. (2013). Social Media as Enabler of Crowdsourcing (pp. 243-255). https://doi. org/10.1108/S1877-6361(2013)0000012016

\section{Pustaka Laman}

https://www.adobe.com

https://www.freepik.com/

https://www.shutterstock.com/ 